\title{
Natural latex graft in lamellar and penetrating sclerectomies in rabbits
}

\author{
Enxerto de látex natural na cicatrização de esclerectomias lamelar e penetrante em coelhos
}

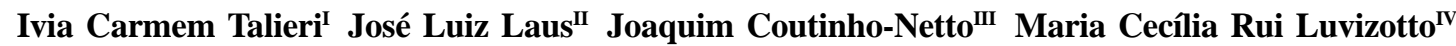 \\ Meiby Carneiro de Paulav
}

\section{ABSTRACT}

The objective of study was to investigate the effects of natural latex with $0.1 \%$ of polylysine on lamellar and penetrating scleroctomies in rabbits. Two groups of twelve rabbits each (lamellar GI and penetrating GII) were studied. Scleral square incisions near the limbus were performed on the left eye of each animal. The latex biomembrane was fixed to the recipient sclera and it covered with a conjunctival flap. The clinical evaluations were followed for 60 days. Aplannation tonometry, binocular indirect ophthalmoscopy and slit-lamp biomicroscopy were performed during evaluation. Bright field microscopy and polarization microscopy were employed. Blepharospasm, graft infection, mucoid ocular discharge and chemosis were not observed in either treatment group. The conjunctival hyperemia varied from moderate to hardly noticeable. The postoperative IOP was not statiscally significant, comparing to the preoperative IOP, for GI and GII. The histopathology by polarization microscopy showed that the neoformed tissue was primarily dependent on adjacent vascularized tissues and was constituted by collagen type III. Both groups presented optimum graft adhesion to the receiving sclera. The natural latex biomembrane with $0.1 \%$ polylysine constitutes a new alternative for scleral reconstruction. Furthermore, this is a durable material, easy to obtain and manipulate.

Key words: biomaterial, graft, healing, sclera, scleroplasty.

\section{RESUMO}

Este trabalho teve como objetivo investigar os efeitos do látex natural com polilisina a $0,1 \%$ na cicatrização de esclerectomias lamelar e penetrante em coelhos. Foram estudados dois grupos de 12 coelhos (GI - lamelar e GII penetrante). As esclerectomias foram realizadas no olho esquerdo de cada animal. A biomembrana de látex foi fixada à esclera receptora e foi recoberta com conjuntiva bulbar. As avaliações clínicas foram realizadas durante 60 dias. Para tal, empregaram-se a tonometria de aplanação, a oftalmoscopia indireta binocular e a biomicroscopia em lâmpada de fenda. Realizou-se análise histopatológica das escleras em microscopia de luz e sob luz polarizada. Não houve blefarospasmo, secreção ocular mucóide, quemose ou sinais de infecção do enxerto em ambos os grupos. A hiperemia conjuntival variou de moderada a tênue. Não houve diferença estatisticamente significativa entre a pressão intraocular do período pós-operatório e do período pré-operatório, para o GI e o GII. A histopatologia por microscopia de polarização demonstrou que o tecido neoformado foi oriundo de tecidos vascularizados adjacentes e constituídos por colágeno do tipo III. Os dois grupos apresentaram ótima adesão do enxerto de látex à esclera receptora. A biomembrana de látex natural com polilisina a $0,1 \%$ representa uma alternativa para a reconstrução escleral, além de apresentar fácil obtenção, manuseio e durabilidade.

Palavras-chave: biomaterial, enxerto, cicatrização, esclera, escleroplastia.

\footnotetext{
'Hospital Veterinário, Centro de Ensino Superior de Maringá (CESUMAR), 87014-250, Maringá, PR, Brasil. E-mail: iviact@gmail.com.*Autor para correspondência.

"Departamento de Clínica e Cirurgia Veterinária, Faculdade de Ciências Agrárias e Veterinárias (FCAV), Universidade Estadual Paulista (UNESP), Jaboticabal, SP, Brasil.

IIIDepartamento de Bioquímica e Imunologia, Faculdade de Medicina de Ribeirão Preto (FMRP), Universidade de São Paulo (USP), Ribeirão Preto, SP, Brasil.

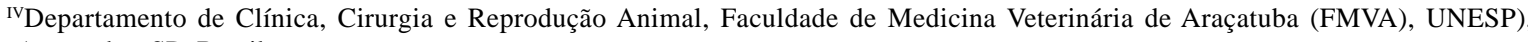
Araçatuba, SP, Brasil.

VInstituto Agronômico do Paraná (IAPAR), Ponta Grossa, PR, Brasil.
} 


\section{INTRODUCTION}

A new biomaterial (Biocure, Pele Nova Biotecnologia S/A, Ribeirão Preto, Brazil - PCT/BR 97/ 00054) was developed at the Ribeirão Preto Medicine College of the University of São Paulo, using natural latex extracted from the Hevea brasiliensis rubber tree. The membrane was obtained through a cold polarization of the latex constituents. In experimental studies, latex biomembrane showed to be useful for repairing defects of the esophagus, peritoneum, pericardium (SADER et al., 2000), bulbar conjunctiva (PINHO et al., 2004) and dental alveolus (BALABANIAN et al., 2006). It was successfully used for the reconstruction of the tympanic membrane perforation (OLIVEIRA et al., 2003) and for the treatment of chronic phlebopatic cutaneous ulcers (POTÉRIOFILHO et al., 1999).

Disorders of the sclera constitute a group of congenital and acquired diseases. Most of them result in scleral stretching or necrosis and exhibition of the underlying uveal tract leading to surgical treatment (GREEN \& BRANNEN, 1995; SKOROBOHACH \& HENDRIX, 2003; TI \& TAN, 2003).

In 1934, Van der Hoeve (NGUYEN \& FOSTER, 1999) first recommended the use of grafts in scleromalacia perforans in human, using mucous membranes. Several biological or synthetic materials were studied in the scleroplasties: allogenous sclera (CARPINETO et al., 2002; GOPAL et al., 2003; ÖZCAN et al., 2005), autogenous sclera (MA et al., 2002), corneosclera (SRIDHAR et al., 2002), allogenous corneal lamellar (TI \& TAN, 2003; ÖZCAN et al., 2005), fresh cadaveric limbus (SONY et al., 2005), amniotic membrane grafting (TI \& TAN, 2003; MA et al., 2002; SRIDHAR et al., 2002; FAIRBANKS et al., 2003), fascia lata (ÖZCAN et al., 2005), elastic layer of the aorta (KANIUKOV et al., 1999), autogenous periosteum (NGUYEN \& FOSTER, 1999), autogenous buccal mucosa and conjunctiva (MURDOCH et al., 1997), dura mater (TI \& TAN, 2003; KANIUKOV et al., 1999), auricular cartilage (GREEN \& BRANNEN, 1995; NGUYEN \& FOSTER, 1999) and autogenous dermal grafts (NGUYEN \& FOSTER, 1999).

In animals, several tissues were successfully used: porcine small intestinal submucosa (LEWIN, 1999), autogenous temporalis fascia (SKOROBOHACH \& HENDRIX, 2003), equine pericardium (BARROS et al., 1996) and equine renal capsule (ANDRADE et al., 2004) and frozen canine amniotic membrane (BARROS et al., 2005). There are reports of the use of synthetic grafts, as the polytetrafluoroethylene (Gore-Tex ${ }^{\mathrm{TM}}$ ) (NGUYEN \& FOSTER, 1999), the expanded polytetrafluoroethylene (Gore-Tex ${ }^{\mathrm{TM}}$ Soft Tissue Patch), the polymethylacrylate (Miragel ${ }^{\mathrm{TM}}$ ) and the polyethylene terephthalate $\left(\right.$ Dracon $\left.^{\mathrm{TM}}\right)$ (WHITMORE et al., 1990). The scleral graft should be accompanied by conjunctival flap, because it provides vascularization, avoids epithelial loss, maintains the graft integrity and acts in the prophylaxis of the infection (LEWIN, 1999; TI \& TAN, 2003; ÖZCAN et al., 2005).

In this study we investigated the healing of the sclera in rabbits presenting experimental lamellar and penetrating lesions using the natural latex biomembrane with $0.1 \%$ polylysine, according to bright field microscopy and polarization microscopy.

\section{MATERIALS AND METHODS}

Twenty-four adult male and female albino New Zealand rabbits were used. They were submitted to slit-lamp biomicroscopy (Portable Slit Lamp/SL-14, Kowa), indirect ophthalmoscopy (Heine - Omega 180, Heine), applanation tonometry (TonoPen XL, Mentor $\mathrm{O} \& \mathrm{O}$ ), and fluorescein test (Fluorescein Strips, Ophthalmos Ltda). The rabbits were divided into two groups of twelve members each. Healing events were investigated in the lamellar scleroplasties with natural latex biomembrane in GI and in the penetrating scleroplasties in GII.

The protocol used for anesthesia was acepromazine $(0.5 \mathrm{mg} / \mathrm{kg}$ SC - Acepran $1 \%$, Univet $)$, xylazine (1.0mg kg ${ }^{-1}$ - Rompun, Bayer) and tiletamine / zolazepam (15mg kg ${ }^{-1}$ IM - Zoletil, Virbac). Scleroplasty was performed on the left eye. Tetracaine and epinephrine eyedrops (Colírio Anestésico, Allergan) were administered before the preparation of the surgical bed.

The microsurgical procedures were performed with the aid of an operating microscope (Surgical Microscope MC - M 900, DF Vasconcellos) of 16X magnification. Bulbar conjunctiva was cut with scissors and retracted for scleral beds exposure. Scleral square incisions (lamellar - GI and penetrating - GII) of $4.0 \times 4.0 \mathrm{~mm}$ were performed in a 9-12 clockwise position, near the limbus. The depth of the lamellar sclerectomy corresponded to half of the stromal thickness (Figure $1 \mathrm{~A})$. In the penetrating sclerectomy, the scleral defect was removed up to the lamina fusca (Figure 1B).

Units of natural latex biomembrane with 4.0 $\mathrm{x} 4.0 \mathrm{~mm}$ and $0.5 \mathrm{~mm}$ thick and sterilized in ethylene oxide were used. The biomembrane was fixed to the recipient sclera using an interrupted pattern with 9-0 mononylon (Mononylon 9-0, Cirumédica) (Figure 1C), and then it was covered with conjunctival flap sutured in the 


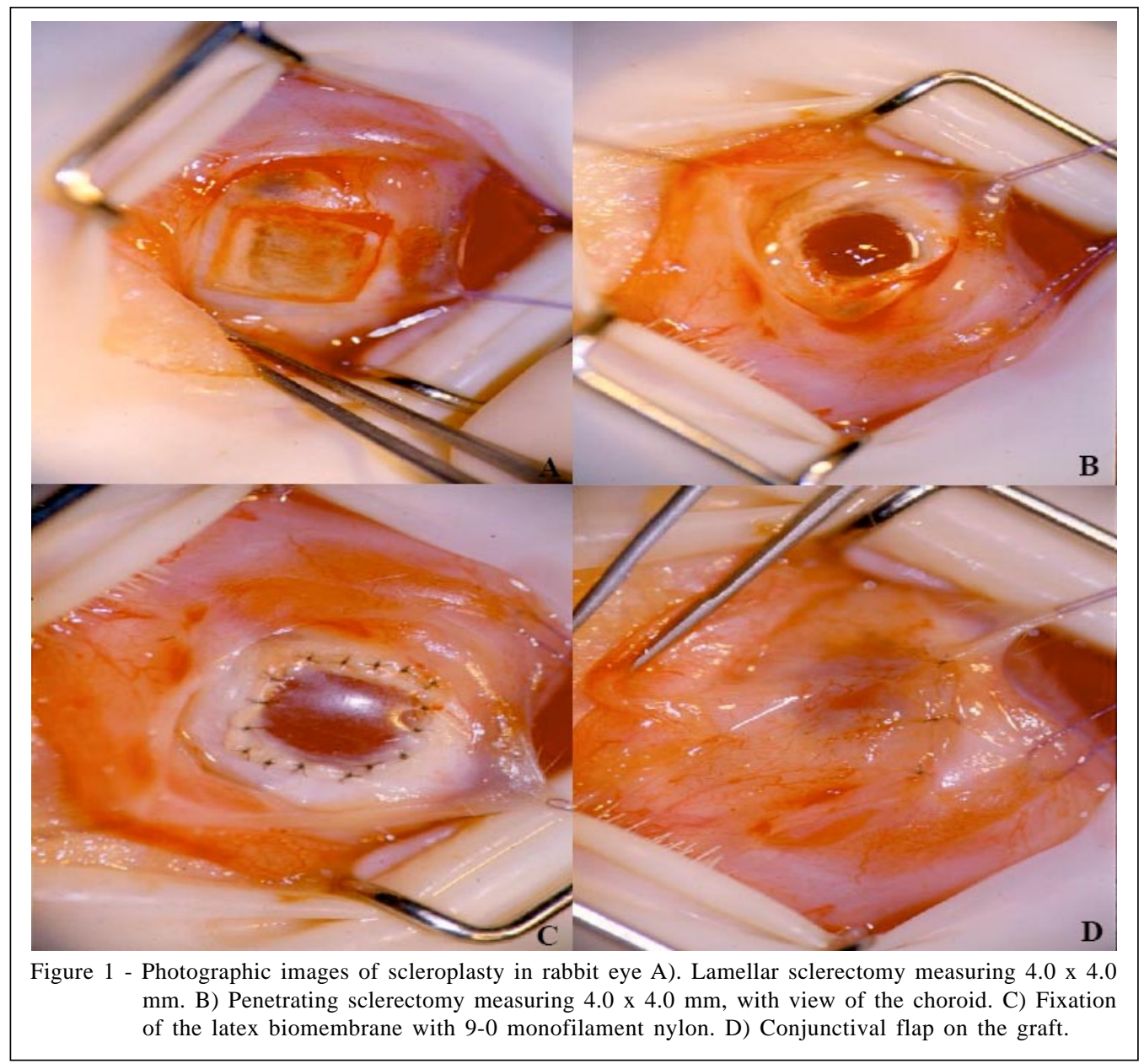

periphery of the limbus and in the adjacent conjunctiva (Figure 1D). The conjunctival flap was kept during the whole experiment.

After the surgery, the rabbits were treated with flunixin meglumine (1mg kg-1 SC - Banamine, Schering-Plough Veterinária) and meperidine (12 $\mathrm{mg} \mathrm{kg}^{-1}$ SC - Dolosal, Cristália), twice a day for the first three postoperative days. Topically, flurbiprophen (Ocufen, Allergan) and tobramicin (Tobrex, Allergan) eyedrops were applied twice a day for seven days.

Clinical evaluations started on the first day of the postoperative period and were performed at 24$\mathrm{h}$ intervals for 60 days, using slit-lamp biomicroscopy in dark room. The evaluated ocular signs were blepharospasm, ocular discharge, chemosis, conjunctival hyperemia, reflex uveitis, as well as the viability and the time length of the graft.

The intraocular pressure was measured by applanation tonometry in left eye on the preoperative day and on the $1^{\text {st }}, 3^{\text {rd }}, 7^{\text {th }}, 12^{\text {th }}, 15^{\text {th }}, 22^{\text {nd }}, 30^{\text {th }}, 35^{\text {th }}, 45^{\text {th }}$, $55^{\text {th }}$ and $60^{\text {th }}$ days of the postoperative period. The results were submitted to variability tests in order to verify if there were differences between the groups and throughout the days, with a significance level of $5 \%$. The Dunnett test was used to compare the differences between the means and the preoperative and postoperative IOP.

Indirect ophthalmoscopy was performed in the operated eye after induction of mydriasis with tropicamide eyedrops (Mydriacyl, Allergan) on the $3^{\text {rd }}$, $7^{\text {th }}, 15^{\text {th }}, 30^{\text {th }}, 45^{\text {th }}$ and $60^{\text {th }}$ postoperative days.

Two animals of each group were evaluated to histopathology for each period $\left(1^{\text {st }}, 3^{\text {rd }}, 7^{\text {th }}, 15^{\text {th }}, 30^{\text {th }}\right.$ and $60^{\text {th }}$ days). The samples were stained with either hematoxylin-eosin, Masson trichrome or picrosirius.

\section{RESULTS}

\section{Clinical evaluation}

Conjunctival hyperemia was moderate on the $1^{\text {st }}$ day, hardly noticeable by the $5^{\text {th }}$ day, becoming tenuous on the $30^{\text {th }}$ day in both groups. Mucoid ocular discharge was observed in only two animals of each group, being moderate on the $1^{\text {st }}$ day and modest on

Ciência Rural, v.39, n.6, set, 2009. 
the $3^{\text {rd }}$ day. Chemosis was modest on the $1^{\text {st }}$ day, fading completely on the $5^{\text {th }}$ day in two rabbits of each group. Flare and miosis were not observed in any of the groups.

On the $3^{\text {rd }}$ day, two rabbits of GII presented a small dimension clot, permeating the superior medial portion of the vitreous, close to the penetrating sclerectomy. On the $15^{\text {th }}$ day, there was a decrease in the size of the clots in both animals and by the day $30^{\text {th }}$, they were permeating the inferior medial of the vitreous. On the day $60^{\text {th }}$, they were no longer observed. Regarding intraocular pressure there was no significant difference between the groups $(\mathrm{P}>0.05)$ and throughout the days $(\mathrm{P}>0.05)$ as shown in table1.

\section{Histopathology}

In order to better describe the results, the area on the graft in both groups was denominated "conjunctival face". The area below the graft was denominated "scleral face” in GI, and "choroidal face" in GII.

\section{Hematoxilin and eosin}

In both groups, the inflammation was predominantly polymorphonuclear on the $1^{\text {st }}$ day in the conjunctival and scleral faces (GI) and choroidal face (GII), and also between the choroid and the sclera. From the $3^{\text {rd }}$ day on, there was a decrease of the polymorphonuclear infiltrate. Mononuclear cells became evident on the $3^{\text {rd }}$ day, increasing gradually through the end of the evaluation. On the $30^{\text {th }}$ day, the inflammation became chronic granulomatous. These

Table 1 - Means values for the IOPs of left eyes (applanation tonometry) of rabbits submitted to lamellar (GI) and penetrating (GII) scleroplasties with latex biomembrane using polylysine at $0.1 \%$. The Dunnett test was used to compare the differences between the means and the preoperative and postoperative IOP.

\begin{tabular}{lrc}
\hline Day & Mean (mmHg) & Difference between mean \\
\hline 0 & 11.0 & \\
1 & 9.9 & -1.1250 \\
3 & 9.8 & -1.2417 \\
7 & 11.0 & -0.0417 \\
12 & 12.5 & 1.4583 \\
15 & 11.3 & 0.2917 \\
22 & 11.5 & 0.4583 \\
30 & 10.5 & -0.5417 \\
35 & 13.3 & 2.2083 \\
45 & 10.5 & -0.5417 \\
55 & 10.5 & -0.5417 \\
60 & 13.5 & 2.4583 \\
\hline
\end{tabular}

Significant difference $(\mathrm{P}>0,05)$ is indicated with * inflammatory cells, originated from the uvea and the adjacent episclera, were observed in the choroidal and conjunctival faces of the graft. In some areas, they crowded around many fibroblasts and few collagen fibrils, forming granulomas in both faces of the graft. In GI, on the $60^{\text {th }}$ day, the chronic granulomatous inflammation persisted moderately, including the biomembrane (Figure 2A). Giant cells were observed around the graft from the $7^{\text {th }}$ day on in GI and from the $15^{\text {th }}$ day on in GII, increasing on the $60^{\text {th }}$ day.

In both groups, the blood vessels of the choroid were intensely swollen on the $1^{\text {st }}$ day, fading on the $15^{\text {th }}$ day in GI and remaining up to the $60^{\text {th }}$ day in GII. In five animals of GII, retinal edema and sub retinal hemorrhage focuses were observed in every period of the evaluation, except on the $60^{\text {th }}$ day.

In the GII the fibroblastic migration to the lesion bed, in the scleral and conjunctival faces began on the $3^{\text {rd }}$ day of the evaluation, formed by a row of cells. On the $7^{\text {th }}$ day, in the peripheries of the graft and adjacent to the borders of the lesion, fibroblasts were found in moderate amount, migrating to both faces of the graft. The neoformed tissue started to involve the whole graft on the $15^{\text {th }}$ day of the evaluation and on the $30^{\text {th }}$ day it became thicker. In the neoformed tissue of both faces of the graft, neovessels were observed firstly on the $15^{\text {th }}$ day in the periphery of the grafts, reaching their largest values on the $60^{\text {th }}$ day.

As the sclera was absent due to penetrating sclerectomy, the fibroblasts migrated from the choroid and the episclera (Figure 2B) to the choroidal and conjunctival faces, respectively, through a fibrin net. At the end of the evaluation, a great number of fibroblasts, few fibrocytes and great amount of collagen fibrils were observed, characterizing the maturation of the healing tissue (texto removido). Neovessels increased from the $7^{\text {th }}$ day throughout the end of the evaluation.

\section{Masson trichrome}

Fibroblastic migration (Figure 2C) and the neoformation tissue were observed as for the hematoxilin-eosin. Fibroblasts were predominant compared to collagen fibrils in both faces of the graft in GI (texto removido). Collagen fibrils, marked in light blue, permeated the fibroblasts (texto removido). In GII, on the $30^{\text {th }}$ and $60^{\text {th }}$ days, neoformed tissue with a larger amount of collagen fibrils was observed in the choroidal face of the graft (Figure 2D). Neoformed vessels were observed in both groups.

On the $60^{\text {th }}$ day of the evaluation, the neoformed tissue showed to be more mature in both groups. In GI, a larger amount of collagen fibrils and 


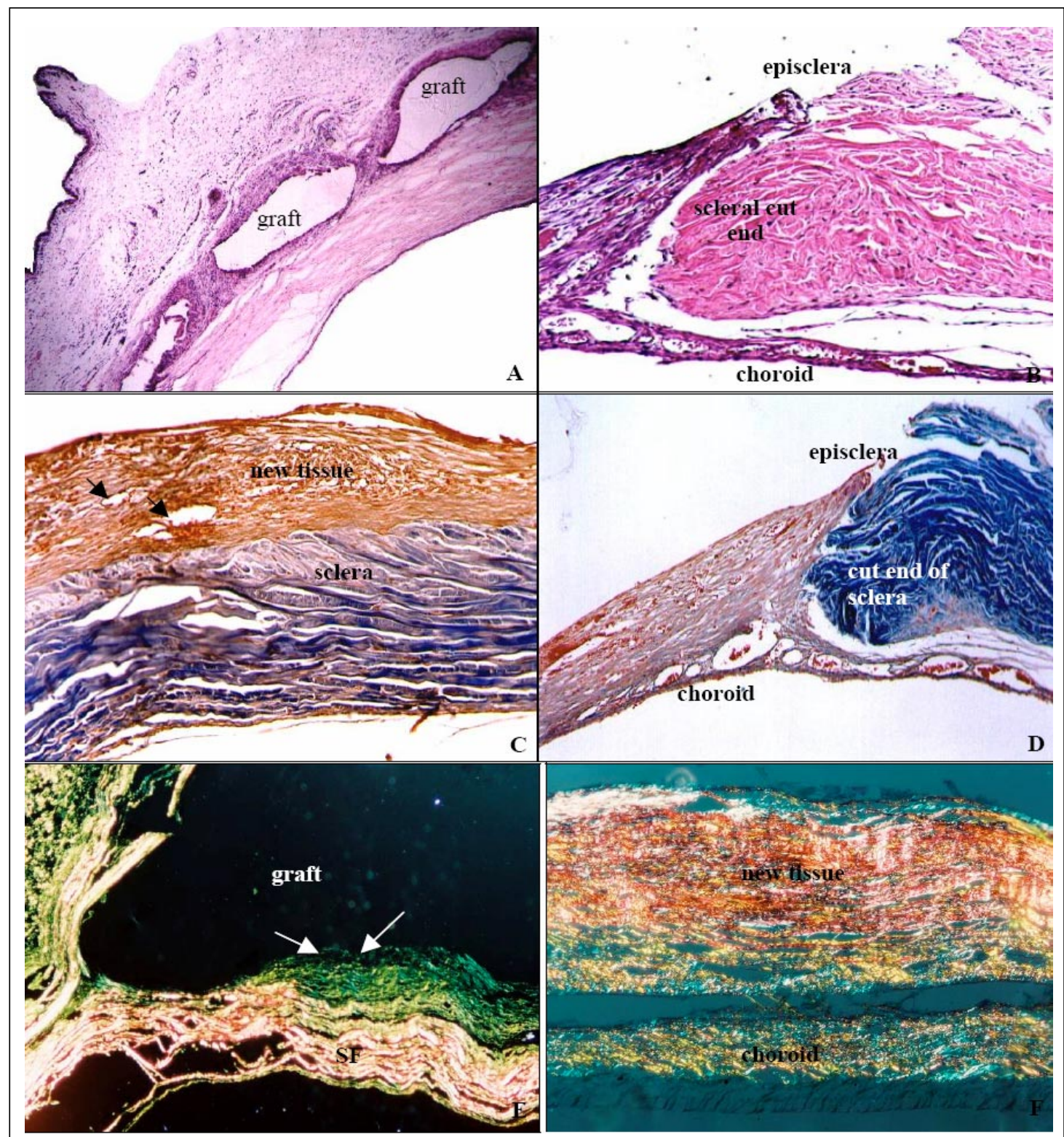

Figure 2 - Photomicrographs of rabbit sclera submitted to the scleroplasty with latex biomembrane and stained with Hematoxylin and Eosin (A e B), Masson trichrome (C e D) e Picrosirius (E e F). A) Lamellar scleroplasty on the $60^{\text {th }}$ postoperative day. Inflammation involving the graft can be observed (x 40). B) Penetrating scleroplasty on the $7^{\text {th }}$ postoperative day. Area of lesion in the scleral cut end is seen. Conjunctival and vascular proliferation can be seen extending from the episclera and choroids (x100). C) Lamellar scleroplasty on the $15^{\text {th }}$ postoperative day. Neoformed tissue is characterized by fibroblasts, collagen fibrils and neoformed vessels (arrows) on the scleral face of the graft (x 200). D) Penetrating scleroplasty on the $7^{\text {th }}$ postoperative day. Observe the newly formed tissue through the migration of fibroblasts originating from of the episclera and of the choroid (c) (x 100). E) Lamellar scleroplasty on the $60^{\text {th }}$ postoperative day. Neoformed tissue (arrows) on scleral face (SF) constituted by type III collagen fibers (x 40). F) Penetrating scleroplasty on the $60^{\text {th }}$ postoperative day. Observe that the neoformed tissue is in organization in choroidal face of the graft, presenting type I and III collagen fibers (x 100).

few fibroblasts were observed in the scleral face of the graft (Figure 2C). In the choroidal face of the graft of GII, however, neoformed tissue with young collagen fibrils was observed in light blue, and also mature collagen in dark blue, exhibiting organization.

\section{Picrosirius}

It was observed that the neoformed tissue of both groups has green pigments, from the initial periods of the evaluation, increasing gradually in thickness in the following healing phases. The green 
color suggests tissue formed by type III collagen fibers (Figures 2E). In GII, on the $60^{\text {th }}$ day of evaluation, it was particularly observed that the neoformed tissue presented type I collagen fibers (Figure 2F).

\section{DISCUSSION}

In terms of convenience and availability, the synthetic materials constitute excellent alternatives to biological grafts. Moreover, the donor collagen can be involved with the sclera disease events, being digested by enzymes or being substituted for receiver's fibroblasts, leading to scleral weakness.

The choice for the study of biomembrane with polylysine is due to the results obtained in previous researches (POTÉRIO-FILHO et al., 1999). The property of promoting angiogenesis and the capacity of promoting cellular adhesion and formation of extracellular matrix are relevant for the process. Their physical properties, such as elasticity and molding, are also useful in reparative surgery, besides allowing sterilization in ethylene oxide and being easily obtained (FRADE et al., 2001; OLIVEIRA et al., 2003). It was observed that the addition of $0.1 \%$ amino acid polylysine strengthened the healing effects when applied to native tissue.

This study is based on positive results of conjunctival flap in scleroplasties. Several studies show that it promotes vascularization of the area, maintains the integrity of the graft and acts in the prophylaxis of epithelial losses or infections (LEWIN, 1999; TI \& TAN, 2003).

Blepharospasm was not observed in any of the groups, due to the attention paid to the conjunctival flap, which protected the suture and the areas of the sclera bare (ANDRADE et al., 2004).

The conjunctival hyperemia, more intensely manifested in the initial stages in both groups, is admitted to be a result of the surgical trauma. Unlikely, some severe ocular inflammation has already been found, characterized by blepharospasm and accentuated conjunctival hyperemia, by the use of synthetic graft of polytetrafluoroethylene (HUANG et al., 1994). The researchers observed sutures dehiscent and poor adhesion between graft and surrounding tissue. It is believed that such intercurrences were a result of the non-use of conjunctival covering.

Chemosis was observed in some animals, especially in those of the group submitted to the penetrating scleroplasty. Supposedly, this is the result of manipulation and of direct surgical trauma on the ocular surface, which were certainly superior in that group.
Clinical signs of reflex uveitis such as flare, miosis and iris edema were expected, mainly in GII. However, those signs were not observed in neither of the two groups in despite of the histopathology had showed blood vessels of the choroid intensely swollen on GI and GII. In addition, retinal edema and sub retinal hemorrhage focuses were observed in every period of the evaluation, except on the $60^{\text {th }}$ day in five animals of GII. Certainly, the manipulation in GII justify these histopathologycal alterations.

In regard to intraocular pressure, data show that the surgical trauma in both groups was not enough to produce uveitis. In the GII, the biomembrane acted quickly as a stamp in the sclera, resisted the intraocular pressure and was sufficiently rigid to avoid distortion of the eye.

It is known that the healing of the sclera depends, excessively, on vascularized adjacent tissue, as the episclera and the uveal tract (DUKE-ELDER \& LEIGH, 1977). Such discoveries were confirmed by Masson trichrome stain.

The latex biomembrane, in both groups, was involved by a conjunctive-vascular capsule. Fibroblasts, collagen fibers and giant cells did not invade the graft, which acted as a support so that the healing tissue could develop around it. The fact of the graft been encapsulated by neoformed tissue instead of incorporated, had already been reported (WHITMORE et al., 1990; WILKIE \& WOLF, 1991; PEZZUTTI et al., 2001) in those scleroplasties in which polytetrafluoroethylene was used.

In the present research, blood vessels were observed in the neoformed tissue. These results were in accordance with the indication that the latex biomembrane is capable of stimulating the angiogenesis of the receiver's tissue, as it had already been pointed out (OLIVEIRA et al., 2003; PINHO et al., 2004). Moreover, it has already been admitted the interference of a vascular growth factor present in the rubber tree Hevea brasiliensis, which would be the inductor of the angiogenesis (OLIVEIRA et al., 2003). It is believed that the fact of been craft made by a simple polymerization method, might have preserved the biological activity of angiogenic substances.

In this study, strong birefringency of the collagen fibers was evident when the picrosirius method was used. The results were in accordance with other researchers' results, who studied the kinetics of the fibroplasia for the distinction among the types of collagen (JUNQUEIRA et al., 1979). It is admitted that in the neoformed tissue, initially, type III collagen fibers prevailed, although with the evolution of the repairing, type I started to prevail. Predominance of types I and III collagen fibers in sclera had already been notified (WATSON \& YOUNG, 2004). 
The results obtained through this study agree with other researchers' results regarding the advantages of using latex biomembrane grafts. The utilization of these grafts in scleral defects deserves attention and it should be advisable to conduct another study with a longer follow up in order to observe the position, size and life span of the latex biomembrane in the sclera.

\section{CONCLUSION}

This research showed that the natural latex biomembrane maintains properties that induce to a fast and regular healing. Among these properties the main ones are cellular adhesion that is processed on its surface; induction of angiogenesis and formation of extracellular matrix and good adherence that maintains the native tissue, serving as support for the growth of fibrovascular tissue, without infection signs or rejection.

\section{ACKNOWLEDGMENTS}

The authors would like to thank: Biochemistry and Immunology Department of Ribeirão Preto Medicine College - University of São Paulo - USP for the donation of the latex biomembrane; CESUMAR (Centro de Ensino Superior de Maringá) for financial support and also CAPES (Coordenação de Aperfeiçoamento de Pessoal de Nível Superior) for providing the scholarship.

\section{REFERENCES}

SADER, S.L. et al. Substituição parcial do pericárdio de cães por membrana de látex natural. Revista Brasileira de Cirurgia Cardiovascular, v.15, n.4, p.338-344, 2000. Disponível em: $<$ http://www.scielo.br/scielo.php?script=sci_arttext\&pid=S010276382000000400008\&lng=pt\&nrm=iso $>$. Acesso em: 1 mar. 2009. Doi: 10.1590/S0102-76382000000400008

PINHO, E.C.C.M. et al. Uso experimental da biomembrana derivada de látex na reconstrução conjuntival. Arquivos Brasileiros de Oftalmologia. v.67, n.1, p.27-32, 2004. Disponível em: <http:// www.scielo.br/scielo.php?script=sci_arttext\&pid=S000427492004000100005\&lng=pt\&nrm=iso>. Acesso em: 1 mar. 2009. Doi: 10.1590/S0004-27492004000100005

BALABANIAN, C.A. et al. Biocompatility of natural latex implanted into dental alveolus of rats. Journal of Oral Science, v.48, p.201-205, 2006. Disponível em: <http:// www.jstage.jst.go.jp/article/josnusd/48/4/48_201/_article>. Acesso em: 1 mar. 2009. Doi:10.2334/josnusd.48.201

OLIVEIRA, J.A.A. et al. Miringoplastia com a utilização de um novo material biossintético. Revista Brasileira de Otorrinolaringologia, v.69, n.5, p.649-655, 2003. Disponível em: <http://www.scielo.br/scielo.php?script=sci_arttext\&pid=S003472992003000500010\&lng=pt\&nrm=iso $>$. Acesso em: $1 \mathrm{mar}$. 2009. Doi: 10.1590/S0034-72992003000500010
POTÉRIO-FILHO, J. et al.. O uso de látex natural com polilisina 0,1\% na cicatrização de úlceras isquêmicas. Revista Brasileira de Angiologia e Cirurgia Vascular, suplemento, S-156, 1999.

FRADE, M.A.C. et al. Chronic phlebophatic cutaneous ulcer: a therapeutic proposal. International Journal of Dermatology, v.40, n.3, p.238-240, 2001. Disponível em: <http://www3.interscience.wiley.com/journal/119016878/ abstract?CRETRY=1\&SRETRY=0>. Acesso em: 1 mar. 2009. Doi: $10.1046 /$ j.1365-4362.2001.00977-2.x

GREEN, M.O., BRANNEN, A.L. Hyperbaric oxygen therapy for beta-radiation - induced scleral necrosis. Ophthalmology, v.102, n.7, p.1038-1041, 1995.

SKOROBOHACH, B.J.; HENDRIX, D.V.H. Staphyloma in a cat. Veterinary Ophthalmology, v.6, n.2, p.93-97, 2003. Disponível em: <http://www3.interscience.wiley.com/journal/ $118853281 /$ abstract?CRETRY $=1 \&$ SRETRY $=0>$. Acesso em: 1 mar. 2009. Doi: 10.1046/j.1463-5224.2003.00285.x

TI, S.E.; TAN, D.T. Tectonic corneal lamellar grafting for severe scleral melting after pterygium surgery. Ophthalmology, v.110, n.6, p.1126-1136, 2003. Disponível em: <http:// www.sciencedirect.com/science?_ob=ArticleURL\&_udi=B6VT248THM8H-S\&_user $=10 \&$ \&doc $=1 \&$ \& fmt $=$ \&_orig $=$ search $\&$ _ sort $=$ d \& vi e w $=$ c \&_a c c t $=$ C $000050221 \&$ \& ve r s i o n $=1 \&$ \& u r l V e r s i o $n=0 \&$ _ u s e r i d $=10 \&$ md5 $=9063 \mathrm{~d} 8 \mathrm{~cd} 1 \mathrm{f} 82 \mathrm{effae} 0914 \mathrm{e} 0 \mathrm{fd} 804 \mathrm{~d} 7 \mathrm{bd}>$. Acesso em: 1 mar. 2009. Doi:10.1016/S0161-6420(03)00260-4

NGUYEN, Q.D.; FOSTER, C.S. Scleral patch graft in the management of necrotizing scleritis. International Ophthalmology Clinics, v.39, n.1, p.109-131, 1999. PMID: 10083910 [PubMed - indexed for MEDLINE]

CARPINETO, P. et al. Management of scleral rupture during retinal detachment surgery: a case report. European Journal of Ophthalmology, v.12, n.6, p.553-555, 2002. PMID: 12510728 [PubMed - indexed for MEDLINE]

GOPAL, L. et al. Tuberculous granuloma managed by full thickness eye wall resection. American Journal of Ophthalmology, v.135, n.1, p.93-94, 2003. Disponível em: < h t t p : / / w w w. s c i e n c ed i r e c t. c o m / science?_ob=ArticleURL\&_udi=B6VK5-47GDKVGK\&_user $=10 \&$ \&doc $=1 \&$ \& $\mathrm{fmt}=\&$ \&_orig $=$ search \&_sort $=$ d \& vi e w $=$ c \&_a c ct $=$ C $000050221 \&$ \& version $=1$ \& u r l V e r s i o $n=0$ \& u s e r i d $=10$ \&md5=03358574e0ba2d791d6f2682dc3ee565>. Acesso em: 1 mar. 2009. Doi:10.1016/S0002-9394(02)01858-5

ÖZCAN, A.A. et al. Surgical management of scleral defects. Cornea, v.24, n.3, p.308-311, 2005

MA, D.H. et al. Amniotic membrane graft for the management of scleral melting and corneal perforation in recalcitrant infectious scleral and corneoscleral ulcers. Cornea, v.21, n.3, p.275-283, 2002

SRIDHAR, M.S. et al. Surgically induced necrotizing scleritis after pterygium excision and conjunctival autograft. Cornea, v.21, n.3, p.305-307, 2002.

SONY, P. et al. Limbal patch graft in surgically induced scleral necrosis. Graefe's Archive for Clinical and Experimental Ophthalmology, v.6, p.1-3, 2005. Disponível em: <http:// 
www.springerlink.com/content/7514k5w1265r2301/>. Acesso em: 1 mar. 2009. doi: 10.1007/s00417-005-0178-1

FAIRBANKS, D. et al. Membrana amniótica no tratamento dos afinamentos corneais e esclerais. Arquivos Brasileiros de Oftalmologia, v.66, n.1, p.71-76, 2003. Disponível em: <http:/ /www.scielo.br/scielo.php?script=sci_arttext\&pid=S000427492003000100014\&lng=pt\&nrm=iso $>$. Acesso em: 1 mar. 2009. Doi: 10.1590/S0004-27492003000100014

KANIUKOV, V.N. et al. The morphological changes in different grafts in scleroplasty. Morfologiia, v.116, n.5, p.32-34, 1999.

MURDOCH, J.R. et al. Autogenous labial mucous membrane and banked scleral patch grafting for exposed retinal explants. Eye, v.11. n.1, p.43-46, 1997.

LEWIN, G.A. Repair of a full thickness corneoscleral defect in a German shepherd dog using porcine small intestinal submucosa. Journal of Small Animal Practice, v.40, n.7, p.340-342, 1999.

BARROS, P.S.M. et al. Reparação experimental de lesões lamelares da esclera de cães com pericárdio xenólogo conservado. Arquivos Brasileiros de Oftalmologia, v.59, n.5, p.462-466, 1996 .

ANDRADE, A.L. et al. Repair of lamellar scleral lesions in dogs with preserved equine renal capsule - short report. Arquivos Brasileiros de Oftalmologia, v.67, n.1, p.16911, 2004. Disponível em: <http://www.scielo.br/ s cielo.ph p ? s c ri p t = sci_art text \& pid = S 0004 27492004000100031\&lng=pt\&nrm=iso $>$. Acesso em: 1 mar. 2009. Doi: 10.1590/S0004-27492004000100031

BARROS, P.S.M. et al. Amniotic membrane transplantation for the reconstruction of the ocular surface in three cases. Veterinary Ophthalmology, v.8, n.3, p.189-192, 2005.
Disponível em: <http://www3.interscience.wiley.com/journal/ 118669427/abstract>. Acesso em: 1 mar. 2009. Doi: 10.1111/ j.1463-5224.2005.00391.x

WILKIE, D.A., WOLF, E.D. Treatment of epibulbar melanocytoma in a dog, using full-thickness eyeball resection and synthetic graft. Journal of American Veterinary Medical Association, v.198, n.6, p.1019-1022, 1991.

PEZZUTTI, S. et al. Politetrafluoroetileno e esclera humana no tratamento cirúrgico de perfuração escleral em coelhos. Arquivos Brasileiros de Oftalmologia, v.64, n.6, p.563567, 2001. Disponível em: <http://www.scielo.br/ scielo.php? script=s ci_art text \& pid=S 0004 27492001000600012\&lng=pt\&nrm=iso $>$. Acesso em: 1 mar. 2009. Doi: 10.1590/S0004-27492001000600012

WHITMORE, W.G. et al. Scleral reinforcement in rabbits using synthetic graft materials. Ophthalmic Surgery, v.21, n.5, p.327-330, 1990.

HUANG, W.J. et al. Clinicopathologic study of Gore-Tex patch graft in corneoscleral surgery. Cornea, v.13, n.1, p.82-86, 1994

DUKE-ELDER, S.; LEIGH, A.G. Diseases of the sclera. In: DUKE-ELDER, S. System of Ophthalmology. St. Louis: Mosby, 1977 . p.995-1056.

JUNQUEIRA, L.C. et al. Picrossirius staining plus polarization microscopy, a specific method for collagen detection in tissue sections. Histochemical Journal, v.11, n.4, p. 447-455, 1979.

WATSON, P.G.; YOUNG, R.D. Scleral structure, organization and disease. A review. Experimental Eye Research, v.78, n.3, p.609-623, 2004. 